\title{
Evaluating the Importance of Social Capital for the Conversion of the Forms of Capital: A Critical Approach to the Bourdieusian Model
}

\section{Sermaye Biçimlerinin Dönüşümü Açısından Sosyal Sermayenin Öneminin Değerlendirilmesi: Bourdieu'nun Modeline Eleştirel Bir Yaklaşım

\author{
Durmus Ali YÜKSEK*
}

\begin{abstract}
In The Forms of Capital, Pierre Bourdieu offers significant insight into the nature of the relationship among economic, cultural, and social capital at the individual level. However, his perspective in the interchangeability among these forms of capital includes neither the more comprehensive conceptualization of the conversion processes occurring at the group level, nor the applicability of symbolic capital throughout the conversions. In this study, I focus on the concept of social capital, conceptualize it as a master capital to develop the Bourdieusian model of conversions, and present my own conceptual approach while addressing the shortcomings of the Bourdieusian model. In my conceptualization, social capital, functioning both as a connector and a transmitter between individuals, facilitates the examination of the more complex group-level conversions. Thus, this enlargement of the Bourdieusian model of conversions provides a more encompassing understanding of the strategies that individuals apply to compete for resources and positions in society.

Keywords: Social capital, conversion theory, Pierre Bourdieu, forms of capital, interconvertibility
\end{abstract}

Öz

Sermaye Biçimleri adlı çalışmasında Pierre Bourdieu birey seviyesindeki ekonomik, kültürel ve sosyal sermaye arasındaki ilişkinin doğasını anlamaya yönelik önemli öngörülerde bulunmaktadır. Ancak, onun bu sermaye biçimlerinin birbirlerine dönüşebilmelerine yönelik bakış açısı ne daha kapsamlı olan grup seviyesindeki dönüşüm süreçlerini ne de bu dönüşümler esnasında sembolik sermayenin kullanımını içermektedir. $\mathrm{Bu}$ çalışmada, sosyal sermaye kavramı üzerine odaklanılmış, Bourdieu'nun dönüşüm modelinin geliştirilmesi için sosyal sermaye bir egemen sermaye biçimi olarak kavramsallaştırılmış ve Bourdieu'nun modelinin eksikliklerinin giderilmesi amacıyla yeni bir kavramsal model ortaya konmuştur. Bu yeni modelde, sosyal sermaye bireyler arasında bir bağlayıcı ve aktarıcı olarak çalışmakta ve daha karmaşı olan grup seviyesindeki sermaye dönüşümlerinin gözlemlenmesini kolaylaştırmaktadır. Böylece, Bourdieu'nun dönüşüm modelinin bu şekilde geliştirilmesi bireylerin toplum içinde kaynaklara ve pozisyonlara erişmek için uygulamış oldukları stratejilerin daha iyi bir şekilde anlaşılmasını sağlamaktadır.

Anahtar Kelimeler: Sosyal sermaye, dönüşüm teorisi, Pierre Bourdieu, sermaye biçimleri, birbirine dönüştürülebilirlik

\section{Introduction}

In his inspiring piece, The Forms of Capital, Bourdieu (1986) contributed two important and distinct understandings of the concept of capital to the sociological literature, different from Marx (1995). These contributions are his conceptualization of different forms of capital and his conceptualization of the conversions among these forms of capital. Bourdieu's contribution to the concept of capital is manifested through his varied understanding of capital, namely capital as both material in the interested form and immaterial in the disinterested form. Additionally, Bourdieu developed the interconvertibility principle, which asserts the interchangeability among economic, cultural, and social capital alike. For Bourdieu, this interconvertibility principle ensures a better understanding of the ongoing competition among individuals for valued resources and positions in societies via capital.

Even though Bourdieu (1986) has provided a unique perspective on the forms of capital and on the conversion processes among them, his theory still lacks two important aspects: first, his conception of the conversion processes restricts itself to the individual level, thus focusing on the conversions within individuals; and second, his conception of the conversion processes does not include the functioning of symbolic capital. I argue that while

\footnotetext{
*Dr. Milli Savunma Bakanlığı, durmusaliyuksek@gmail.com.tr.
}

Yüksek, A. D., (2018). Evaluating the Importance of Social Capital for the Conversion of the Forms of Capital: A Critical Approach to the Bourdieusian Model, Gaziantep University Journal of Social Sciences, 17 (3), 1090 1106, Submission Date: 24-01-2018, Acceptance Date: 09-07-2018.

Araştırma Makalesi. 
the Bourdieusian model of conversion among the forms of capital addresses the relatively simple individual-level transformations, it does not adequately cover the more important group-level transformations that occur between individuals through their usages of social capital. Thus, in my conceptualization of the conversion among the forms of capital, social capital becomes a master capital that allows individuals to enhance their social positions in the stratified society. This understanding of social capital facilitates the examination of the more complex group-level transformations and the conceptualization of a broader and more comprehensive model of conversions among the forms of capital, including symbolic capital.

To develop the Bourdieusian model of the conversion of the forms of capital and present my own conceptual approach, here I will first focus on how Bourdieu (1986) distances himself from Marxism and how this estrangement affects his conceptualization of the concept of capital different from Marx (1995). Second, I will examine each form of Bourdieu's capital separately in detail. Third, I will investigate Bourdieu's understanding of the conversion among different forms of capital and reveal the shortcomings of his model. Finally, I will attempt to develop his model and present my own conceptual approach of the conversion of the forms of capital while removing the shortcomings of the Bourdieusian model.

\section{Bourdieu and the Forms of Capital}

The concept of capital can be traced back to Karl Marx who argues that money and commodities are capital only insofar as they emphasize two distinct properties: an investment with expectations of return and a surplus value generated by the investment (Marx, 1995; Lin, 2001). Capital, for Marx (1995), as the potential investment by the capitalist, generates capital as a surplus value at the end of the production process only for the capitalist, not for the laborer. In this sense, this process only sustains the laborers' subsistence so that they can continue providing labor for the production process. However, the same process provides a surplus value for the capitalist so that they can use a significant portion of it as capital for later investments. In this regard, Marx's conception of capital is based on the exploitative social relations between two classes: capitalists and laborers (Marx, 1995; Lin, 2001).

Bourdieu's (1986) conception of capital differs from Marx's (1995) in relation to his critical dialogue with Marxism. As Swartz (1997) has identified, Bourdieu develops Marx's analysis of capital through distancing himself from Marxism in three ways. First, Bourdieu extends Marx's notion of economic interest to noneconomic goods and practices, thus transcending its narrow economicism and expanding the universe of exchanges from an economically self-interested perspective to a noneconomic, and therefore disinterested perspective (Swartz, 1997; Desan, 2013). Following Weber's sociology of religion, Bourdieu (1986) posits that all action is interested, either material or symbolic, and an interested action cannot be produced without producing its negative counterpart, disinterestedness. In other words, the material forms of exchange in Marx's sense should not only represent the economic forms of capital but should also include the immaterial forms of exchange in the form of other types of capital. This is required to ensure the more effective and easier social and cultural reproduction of the social order in society. This assertion leads us to the second way that Bourdieu distances himself from Marxism.

Bourdieu conceptualizes capital in all forms of power, whether they are material, cultural, social, or symbolic (Swartz, 1997). According to Bourdieu, when resources become objects of struggle for individuals, they become capital (Bourdieu, 1986). Therefore, Bourdieu does not restrict his perspective to economic capital in the form of money and property as Marx does. Instead, he extends capital to include cultural capital in the form of cultural goods and services including educational credentials, social capital in the form of acquaintances and networks, and symbolic capital in the form of legitimation (Bourdieu, 1986). In addition to the 
extension of capital into several forms, another way Bourdieu expands Marx's theory is claiming the possible conversion ${ }^{\mathrm{i}}$ of one form of capital into another. The conversion of capital constitutes a central focus in Bourdieu's sociology since this process provides individuals and groups an opportunity to supplement a certain form of capital by accumulating another, thus to maintaining and/or enhancing their social positions in the stratified society (Bourdieu, 1986).

The third way that Bourdieu distances himself from Marxism is his focus on the symbolic systems such as art, science, education, literature, and religion, and the impact they have on the reproduction of social inequality (Swartz, 1997). Bourdieu argues that Marxism underestimates the importance of such symbolic systems and their effects on the symbolic dimension of power relations; therefore he develops a sociology of symbolic forms and a theory of symbolic violence and capital to provide theoretical analyses of such systems (Bourdieu, 1984; Swartz, 1997).

In light of the three theoretical arguments that Bourdieu developed to distance himself from Marxism, capital, for Bourdieu, refers to "what makes the games of society-not least, the economic game - something other than simple games of chance offering at every moment the possibility of a miracle" (1986, p. 241). In The Forms of Capital, Bourdieu (1986) provides a significant interpretation of the concept of capital and the relationship among the three fundamental forms of capital. Bourdieu states that "depending on the field" in which it [capital] functions, and at the cost of the more or less expensive transformations which are the precondition for its efficacy in the field in question, capital can present itself in three fundamental guises" (1986, p. 243). These three fundamental forms of capital, which I will address throughout this study, are economic capital, cultural capital, and social capital.

Economic capital refers to the economic goods that individuals have such as property, wealth, and other financial objects. Bourdieu rarely attempted to define economic capital, saying that he didn't want to "dwell on the notion of economic capital, because it is not his area" (Desan, 2013, p. 332). Bourdieu slightly touched on economic capital in The Forms of Capital and argued that "economic capital is at the root of all other types of capital" and these other types of capital are "transformed, disguised forms of economic capital" (Bourdieu, 1986, p. 252). All other types of capital are reducible to economic capital in the final analysis. According to Bourdieu (1986), while all forms of capital are fundamentally (or their basic/fundamental origins) economic in nature, capital also manifests itself in noneconomic ways as social, cultural or symbolic capital. Thus, these forms of capital are treated differently and have varying effects on the application, use, and accumulation of capital.

Bourdieu's conceptualization of different forms of capital other than economic capital is an attempt to extend the common-sense assumption of capital as economic to a more comprehensive perspective in which the power dynamics is depicted as capital operates in noneconomic spheres of social life (Desan, 2013). Cultural capital, in this sense, represents this extension from the logic of economic analysis to ostensibly noneconomic goods and services.

Bourdieu argues that a society's dominant class imposes its culture on the dominated class by engaging in pedagogic action (e.g., education). The pedagogic action provides the unconscious internalization of the values and the symbols of the dominant class in the next generation through symbolic violence, thus reproducing the salience of the dominant culture (Bourdieu, 1977a; Bourdieu \& Passeron, 1977; Lin, 2001). In this sense, Lin (2001, p. 15) defines cultural capital as the "acquisition and misrecognition of the dominant culture and its values." Similar to Lin's (2001) perspective on cultural capital, Lamont \& Lareau (1988) refer to cultural capital as the high status cultural signals in the form of verbal facility, general 
cultural awareness, aesthetic preferences, information about the school system, and educational credentials, which provide individuals the opportunity to exclude themselves from others who are deprived of these cultural signals. Thus, differentiating levels of cultural capital, which demonstrates itself as the "disposal of taste" or consumption of specific cultural forms, marks individuals as members of specific groups or not (Bourdieu, 1984). Aside from the above-mentioned features of cultural capital, there are additional functions of the concept with which I am not concerned in this study. ${ }^{\mathrm{iii}}$

Just as the concept of cultural capital moves away from the logic of economic analysis, so does social capital illustrate the noneconomic potential of capital in the social world. For Bourdieu (1986, p. 248), social capital is "the aggregate of the actual or potential resources which are linked to possession of a durable network of more or less institutionalized relationships of mutual acquaintance or recognition." In other words, social capital is the accumulation of social opportunities via social interaction, such as participating in organizations and meeting with people. According to Bourdieu (1986), one's social capital depends on the size of his/her social connections and on the total volume of capital (the combination of all forms of capital such as economic, cultural, or symbolic) in these social connections' possessions. This means that one's social capital increases with the number of social agents that s/he is connected with in two ways. Resources in the form of social capital may be in one's social connections' possessions or in their social positions (Lin, 2001).

Even though Bourdieu proposes three fundamental forms of capital-economic, cultural, and social - in his analysis of the forms of capital (Bourdieu, 1986), his theoretical perspective actually includes one more fundamental but disguised form of capital: symbolic capital. ${ }^{\text {iv }}$ Symbolic capital comes to the forefront of Bourdieu's argument of capital especially in his conceptualization of the conversion of the forms of capital.

Bourdieu develops his concept of symbolic capital through Weber's notions of charisma and legitimacy and through the extension of Weber's notion of interest (Bourdieu, 1986, 1991; Swartz, 1997). According to Bourdieu (1986), all practices are interested whether directed towards material or symbolic items. Actors pursue not only the economic forms of action and objects depicted as material and interested (e.g., money, gifts, or powerful positions), but also noneconomic forms of action and objects depicted as symbolic and disinterested (e.g., demands for recognition, deference, or obedience) to be able to exchange one from the other (Bourdieu, 1986, 1991; Swartz, 1997). In line with his conceptualization of resources as capital "when they function as a social relation of power by becoming objects of struggle as valued resources" (as cited in Swartz, 1997, p. 43), Bourdieu, like Weber, argues that the exercise of power requires legitimation. In this sense, Bourdieu's concept of "misrecognition," similar to the idea of "false consciousness" in the Marxist tradition, ensures the transformation of economic and political interests present in a set of practices into disinterest and allows the accumulation of symbolic power or legitimacy for specified activities (Bourdieu, 1986; 1977b; Swartz, 1997). Put differently, according to Bourdieu,

Symbolic practices deflect attention from the interested character of practices and thereby contribute to their enactment as disinterested pursuits. Activities and resources gain in symbolic power, or legitimacy, to the extent that they become separated from underlying material interests and hence go misrecognized as representing disinterested forms of activities and resources (as cited in Swartz, 1997, p. 43).

Symbolic capital, in this sense, refers to "denied capital," which disguises the interested (material) characteristics of activities and resources and demonstrates them as disinterested (symbolic), thus providing legitimation (Bourdieu, 1986, 1991; Swartz, 1997). In this way, "individuals and groups who are able to benefit from the transformation of self- 
interest into disinterest" obtain symbolic capital in the form of "recognition, deference, obedience, or service for others" (which have noneconomic, symbolic, and disinterested characteristics) and "accentuate selected personal qualities of elites as supposedly superior and natural" rather than presenting themselves as inferior by obtaining other forms of capital (which have economic, material, and interested characteristics) (Bourdieu, 1986, 1991; Swartz, 1997, p. 43).

With his unique perspective on capital, differing from that of Marx (1995), Bourdieu (1986) provides a more comprehensive understanding of the functions of the various forms of capital in society. In addition, the importance of Bourdieu's theoretical conceptualization of the forms of capital shows itself in the interchangeability among these forms of capital since these conversion processes allow individuals to use their initiatives and strategize for the competition of valued resources in society. Although Bourdieu (1986) provides a conceptual framework to understand the convertibility of different forms of capital, his theoretical argument confines the conversion processes to the individual level. Therefore, further theoretical analyses must closely investigate the conversion processes not only at the individual level but also at the group level. In this regard, an elaboration and critical approach to the Bourdieusian model of conversions, in which both the individual and group level conversion processes are investigated, is presented in what follows.

\section{The Conversion of the Forms of Capital}

Bourdieu's (1986) contribution to the concept of capital is not only his conceptual approach to various forms of capital, but also his theoretical analysis in the interchangeability among economic, cultural, and social capital. Bourdieu (1986, p. 253) states that "the convertibility of the different types of capital is the basis of the strategies aimed at ensuring the reproduction of capital (and the position occupied in social space) by means of the conversions least costly in terms of the conversion work and of the losses inherent in the conversion itself." In other words, through converting their available forms of capital into other forms, individuals might contribute to their overall accumulation of deployable resources and maintain their dominant positions in the stratified society (Bourdieu \& Wacquant, 1992). While individuals can directly acquire resources (either economic, cultural, or social), they can also indirectly increase their resources through the utilization of other forms of resources (Bourdieu, 1986).

Bourdieu (1986) sees economic capital as the ultimate form of capital that all the other forms are reducible to and implies that economic capital remains the ultimate goal for individuals. Thus, Bourdieu (1986) provides his conceptualization of the conversion among the forms of capital within an individual (possible conversion works within an individual) and does not provide a detailed analysis of how the conversion processes occur between individuals. In this sense, this study specifically focuses on the conversion of the forms of capital at both the individual and group levels in an effort to address this research gap.

In its most basic form, the Bourdieusian model of conversion of the forms of capital can be depicted as shown in Figure 1. In particular, the illustration highlights the interchangeability among the different forms of capital. While individuals accumulate economic capital to ensure the reproduction of their class positions, they can also convert their economic capital into either social or cultural capital to provide an additional environment to maintain their social positions. Also, as Bourdieu (1986, p. 252) states, "the different types of capital can be derived from economic capital, but only at the cost of transformation, which is needed to produce the type of power effective in the field in question." From this statement, it is understood that the transformation from economic capital (into either cultural or social capital) occurs with a specific amount of cost. Moreover, the transformation into economic 
capital (from either cultural or social capital) occurs with a potential loss through attrition, which is not comparable to the cost that is needed to convert economic capital into cultural or social capital (Bourdieu, 1986; Anheier, Gerhards, \& Romo, 1995).

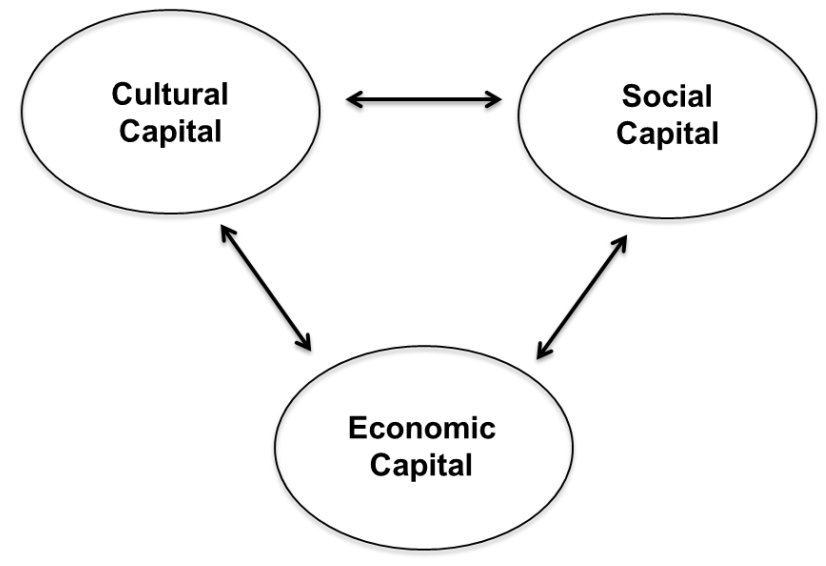

Figure 1: The Basic Model of Conversions among the Forms of Capital

The potential loss during the conversion process occurs depending on the reproducibility, transmissibility, and liquidity of the different forms of capital (Bourdieu, 1986). As Anheier, Gerhards, \& Romo (1995) argue, economic capital is the most liquid and most readily available form of capital for the transformation into social and cultural capital. However, due to their stickier structures, the convertibility of social and cultural capital into economic capital is costlier and more subject to attrition. In this sense, from a simple economic standpoint, the cost to transform economic capital into either social or cultural capital might be seen as waste of time, money, or emotion, whereas, it is, for Bourdieu, "a solid investment, the profits of which will appear, in the long run, in monetary or other forms" (Bourdieu 1986, p. 253). This is a risky investment and the returns of this investment (as either potential loss or potential profit) in the form of economic capital (through the transformations of cultural or social capital into economic capital) determine if it is a success or a failure.

The Bourdieusian model of conversions specifically focuses on the transformations from economic capital into social and cultural capital, and vice versa, and does not "fully theorize the directional link going from cultural to social capital," and vice versa (Lizardo, 2006, p. 780). Since Bourdieu focuses on the economic capital, all the essential transformations occur from or into economic capital in his model. Therefore, in an effort to address this theoretical gap in the Bourdieusian model of conversions, all the potential conversion works among the four forms of capital (including symbolic capital), within and between individuals, will be investigated soon.

According to Bourdieu (1986, p. 252), "there are some goods and services to which economic capital gives immediate access; others can be obtained only by virtue of a social capital of relationships (or social obligations) which cannot act instantaneously." In other words, individuals might acquire some forms of resources immediately through their levels of economic capital at the individual level (e.g., obtaining a degree through converting economic capital into cultural capital); however, they have to have social capital to acquire other resources (e.g., others' volumes of capital, which are not easily accessible through economic capital) through creating social connections with others at the group level. Social capital's productivity reveals itself only through its usage both in the economic capitalization of network resources and in many forms of capital being accumulated and capitalized at the same time (Svendsen, Kjeldsen, \& Noe, 2010). In this sense, Figure 1 remains incapable in 
illustrating the functioning of social capital throughout the conversion processes. Figure 1 illustrates only the conversion processes occurring at the individual level. It does not include the functioning of social capital throughout the conversions as Bourdieu (1986) discusses it, nor does it include the conversion processes at the group level. Therefore, Figure 1 needs to be further developed by considering the conversion processes at both the individual and group levels and the conceptualization of the functioning of social capital for the conversion processes at the group level.

Here, the most important point to see is that there is dependency among the different forms of capital not only within an Ego, but also within the Ego's social network. In other words, the model illustrated in Figure 1 is that of only Ego, but in reality, for example, Ego's economic capital is not only dependent on his/her social and cultural capital, but also on all of his/her alters' forms of capital within his/her local network (Guan, unpublished manuscript). The importance of social capital comes to the forefront of this study in understanding the dependency among different individuals' differing forms of capital in a social network. A simple illustration of this new perspective is shown in Figure 2.

In light of the development in the conceptualizations of the conversions of the forms of capital from Figure 1 to Figure 2 and the arguments made thus far, it can be concluded that the Bourdieusian model of conversions lacks three important aspects of the conversions of the forms of capital: the lack of a clear theorization of (1) the conversion processes between cultural capital and social capital; (2) the functioning of symbolic capital throughout the conversion processes, and (3) the conversion processes occurring between individuals at the group level. I argue that a clear theorization of how social capital functions throughout the conversion processes provides us a unique opportunity to address these shortcomings of the Bourdieusian model of conversions.

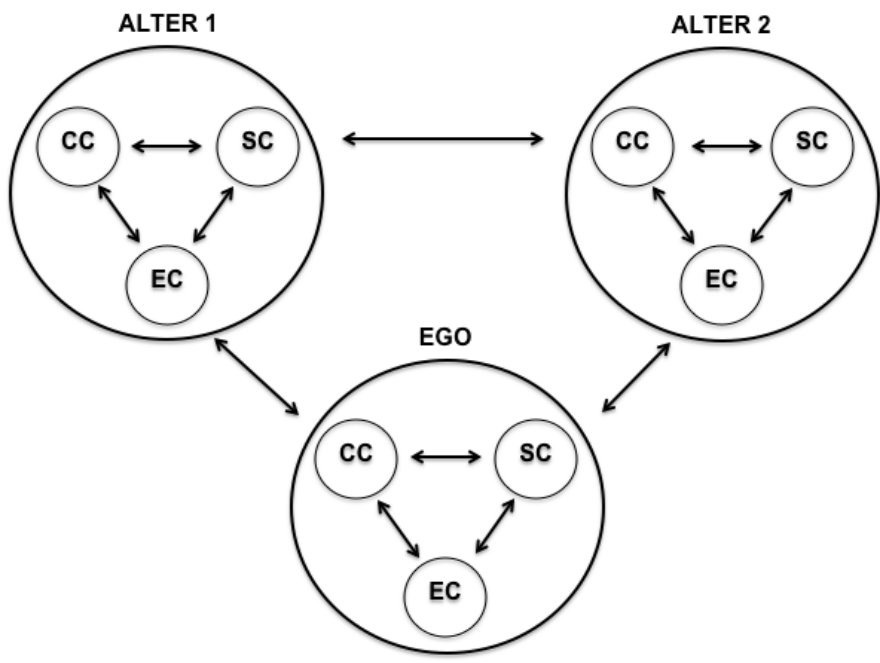

Figure 2: The Basic Model of Conversions among the Forms of Capital at the Group Level

In this regard, the model of conversions among the forms of capital conceptualized in this study starts with the assumption that all individuals have certain amounts of economic, social, cultural, and symbolic capital (EC, SC, CC, and SyC respectively will be used from now on to symbolize these forms of capital). The inclusion of SyC into the current discussion, differently from the Bourdieusian model, which hardly implies it, is important for the conceptualization presented here since the consideration of SyC in the current discussion facilitates the understanding of the conversion processes between individuals from different hierarchical positions in the stratified society, and thus provides a clear perspective to the potential exchanges of symbolic and economic resources between these individuals. 
I argue that the transformations of the forms of capital into other forms occur at two levels: the individual and the group levels. Which form of capital is able to transform into another form and at which level depend on the mobility of the forms of capital. In other words, the transformation of any form of capital into another form and at which level this will occur depend on the usage of SC during the transformation because SC provides mobility to other forms of capital. If the transformation does not require the usage of $\mathrm{SC}$, this transformation will occur at the individual level. If it requires the usage of SC, it will occur at the group level.

At the individual level, an Ego can convert his/her EC and CC amid themselves. For example, a well-endowed individual can buy books or art objects to show his/her cultural capital, and thus convert his/her EC into CC. S/he can also afford any kind of expenditures to obtain a diploma or certificate from a higher education institution to use his/her $\mathrm{CC}$ in the job market. By doing this, s/he will convert his/her EC into CC with an expectation that this CC will return to him/her as EC in the future. This individual can also use his/her EC and CC to obtain SyC in certain environments. However, SyC can only be acquired through social connections with other individuals; therefore the acquisition of SyC requires the usage of SC throughout the transformations of certain forms of capital into other forms at the group level. ${ }^{\mathrm{v}}$

According to Bourdieu (1986, p. 249), "the volume of the social capital possessed by a given agent thus depends on the size of the network of connections he can effectively mobilize and on the volume of the capital (economic, cultural, or symbolic) possessed in his own right by each of those to whom he is connected." Especially focusing on the latter part of this sentence, it can be understood that individuals, who intend to interact with others, see others' volumes of capital (EC, CC, or SyC) as part of their own SCs. Therefore it can be argued that one's SC is directly related and proportional to others' volumes of capital that s/he wants to interact with. Figure 3 provides an illustration of the conceptualization of SC as outlined here. In Figure 3, all individuals have others' volumes of capital added into their SCs. The small circles inside the actors' SCs represent the other two actors (with all their forms of capital) with whom they intend to interact. Since individuals interact with others with the expectation that they will be able to access their volumes of capital, individuals' volumes of capital play a big part in the decisions of interactions. For this reason, conceptually, I argue that both interacting individuals see each other's volumes of capital as part of their SCs, and therefore, to interact with each other, they convert their volumes of capital into their SCs.

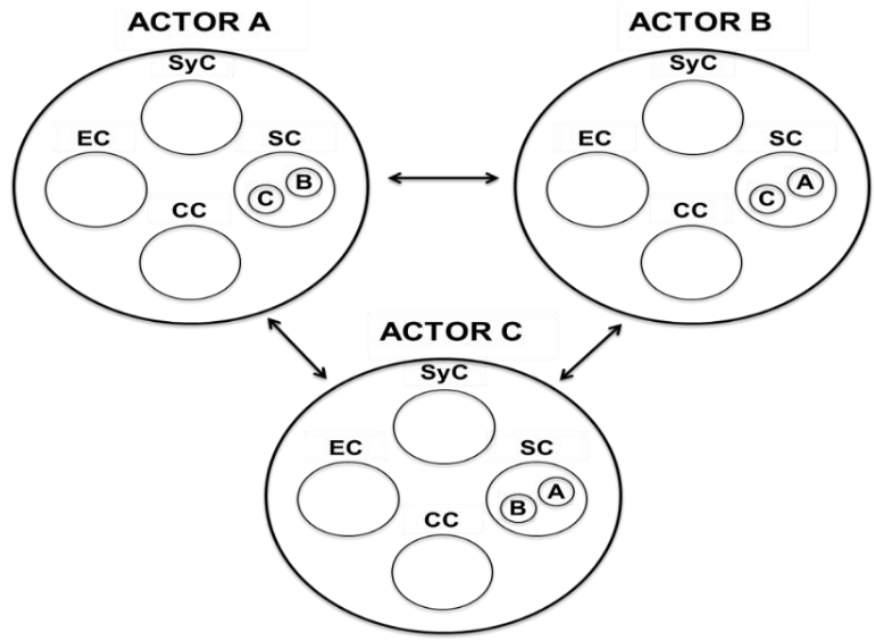

Figure 3: A Simple Illustration of Social Capital between individuals 
The conversion of the volume of capital into SC does not occur tangibly. This conversion only refers to the creation of conceptual links between actors who intend to interact with each other. Individuals have to perform this conversion conceptually before interacting with others to set the stage for interaction, since only by doing this, can the interacting individuals see the others' volumes of capital as accessible (without seeing others' volumes of capital as accessible, they will not interact with them since the objective behind this interaction is to access to others' volumes of capital). ${ }^{\text {vi }}$ That is to say, individuals convert their volumes of capital into their SCs, which actually refers to the potentially interacting individuals that they have, to show them that their volumes of capital are reachable by them, thereby signifying that they are open to interaction with them. An individual's SC, therefore, represents his/her open door to outside social connections that works to send and receive certain resources.

The transformation of the volumes of capital into SC occurs in two different ways. First, if the two potentially interacting individuals meet for the first time and intend to interact, each of them hypothetically converts all of his/her forms of capital (EC, CC, and SyC) into SC to show the other individual his/her available capital capacities. Each individual performs these transformations to ensure that the other individual sees all of his/her capital capacities (EC, CC, and SyC) before determining which form of capital s/he wants to exchange with which form. Second, if the two potentially interacting individuals have already met before and know each other's capital capacities, they only convert their intended forms of capital to exchange with each other. For this reason, on the one hand, when the two individuals meet for the first time and intend to interact with each other, the volume of capital transformed into SC has two meanings. First, it refers to all of these two individuals' forms of capital since this transformation is needed to ensure their decision about what to exchange. Second, after they decide what to exchange, it refers to the intended forms of capital that the interacting individuals attempt to exchange with each other. On the other hand, when two individuals have already met before and intend to interact with each other, it is important and necessary to understand that the volumes of capital transformed into SC, in this case, refer to only the intended forms of capital that the interacting individuals attempt to exchange with each other.

In order to understand the transformation of an individual's volume of capital into his/her SC before the interaction, it is also necessary to understand the differences and similarities between SC and other forms of capital. As Svendsen, Kjeldsen \& Noe (2010, p. 633) argue,

Like [the other forms of capital], [social capital] can be accumulated, stored, and converted. It accrues its owner benefits without being destroyed; in fact it increases by usage. And it facilitates action just as they do. However, unlike the other forms of capital, social capital exists neither in objects nor in people, but between human beings; is increased by usage and cultivation; is wholly informal; and gives access to all the other forms of capital.

In Figure 3, the usage of small circles in each actor's sphere of SC indicates other actors with their volumes of capital and refers to each actor's SC's existence neither in objects nor in him/her, but between them.

As an illustration, it is assumed that two individuals want to interact with each other with the intention of exchanging either material or symbolic rewards. In order to interact with each other, each individual converts his/her volumes of capital (if the two first meet, volume of capital refers to all their forms of capital; if the two have met before, volume of capital refers to the intended forms of capital they want to exchange) into his/her SC and shows the other individual (who actually is part of his/her SC) that s/he is open and ready for interaction. If the two have not already met before, this conversion provides each individual with the 
opportunity to see the other individual's capital capacities (EC, CC, or SyC) and decide on what to exchange. If the two have already met before, this conversion provides each individual with the understanding that the other individual is ready for interaction. Thus, assuming that the interaction occurs between an upper- and a working-class individual, the upper-class individual might give $\mathrm{EC}$ to the working-class individual and receive SyC from $\mathrm{him} /$ her. Thus, the working-class individual sends SyC and receives EC from the upper-class individual. Therefore the upper-class individual converts his/her EC into his/her SC, and the working-class individual converts his/her SyC into his/her SC before interaction. As a result, I argue that all individuals convert their volumes of capital (EC, CC, or SyC) into their SCs before interacting with others. Thus, owing to its unique role throughout these conversions, $\mathrm{SC}$ functions as a connector between individuals.

Due to the indispensability of the usage of SC during the exchange of resources among individuals, SC becomes the essential form of capital for the transformations of the forms of capital into each other at the group level. At the group level, an Ego needs to use his/her SC to acquire SyC or accumulate more EC or CC by accessing his/her alters' EC, CC, or SyC. In terms of the levels of mobility of the forms of capital, an Ego can convert his/her $\mathrm{CC}$ and EC into each other only within himself/herself at the individual level. These two forms of capital do not provide mobility to the Ego since they do not allow him/her to interact with his/her alters. Only by converting his/her EC, CC, or SyC into his/her SC, can the Ego succeed in this objective. The Ego's SC, on the other hand, leads him/her to interact with his/her alters, causing mobility, and thus acquiring SyC and accumulating more EC, CC, or SyC. ${ }^{\text {vii }}$ In this way, SC functions as "a helping hand, a string-pulling, the old boy network" (Bourdieu, 1986, p. 258) which enhances the accumulation of the forms of capital for the Ego through the acquisition of his/her alters' forms of capital. Bourdieu provides an example to the usage of SC for the transformation of an Ego's CC into his/her EC as a return to his/her earlier effort of converting his/her EC into his/her CC. Bourdieu (1986, p. 258) states:

\begin{abstract}
It goes without saying that the dominant fractions [those individuals who have high positions in the structural hierarchy], who tend to place ever greater emphasis on educational investment [through converting their EC into CC], within an overall strategy of asset diversification and of investment aimed at combining security with high yield [through converting their $\mathrm{CC}$ into EC as a return to their earlier effort], have all sorts of ways of evading scholastic verdicts. The direct transmission of economic capital remains one of the principal means of reproduction, and the effect of social capital tends to correct the effect of academic sanctions [the usage of SC facilitates the conversion from CC into EC]. Educational qualifications never function perfectly as currency [the effort to transform EC into CC with an expectation that $\mathrm{CC}$ will contribute to $\mathrm{EC}$ afterwards in a risky investment and may function differently than expected]. They are never entirely separable from their holders: their value rises in proportion to the value of their bearer, especially in the least rigid areas of the social structure.
\end{abstract}

Erickson (1996, p. 224) supports Bourdieu's understanding of SC as a helping hand over the transformation of EC into $\mathrm{CC}$ and states: "advantaged people, including higher-class people [EC], will certainly have better cultural resources [CC],... and [this is] because of the diverse networks $[\mathrm{SC}]$ that advantaged people have."

At the group level, SC functions as a transmitter as well as a connector. During an interaction between an Ego and his/her alter, they need to transform their capacities of EC, $\mathrm{CC}$, or SyC into their SCs to connect to each other. ${ }^{\text {viii }}$ After connecting to each other, both the Ego and his/her alter transmit any form of capital that they want to exchange with their partners through the usage of their SCs. ${ }^{\text {ix }}$ Afterwards, both the Ego and his/her alter receive the transmitted form of capital from their partners through their SCs and insert whatever form of capital they acquire into their capacities of capital, namely what they have already had as capital. This time, however, the conceptual transformation occurs from their SCs into their received forms of capital. For example, if an Ego acquires $\mathrm{CC}$ (EC or SyC) in the form of SC 
from his/her alter, s/he firstly transforms this SC into $\mathrm{CC}$ (EC or SyC) and secondly inserts this CC (EC or SyC) into his/her capacity of CC (EC or SyC). Afterwards, s/he can also convert this CC (EC) into EC (CC) within himself/herself at the individual level. Thus, SC functions first as a connector that links these two actors to each other to interact through the actors' transformations of their resources (EC, CC, or SyC) into their SCs, and second as a transmitter that provides the actors the opportunity to exchange whatever form of capital they need. The example shown in Figure 4 illustrates how these conversions occur and how SC functions throughout the conversion process.

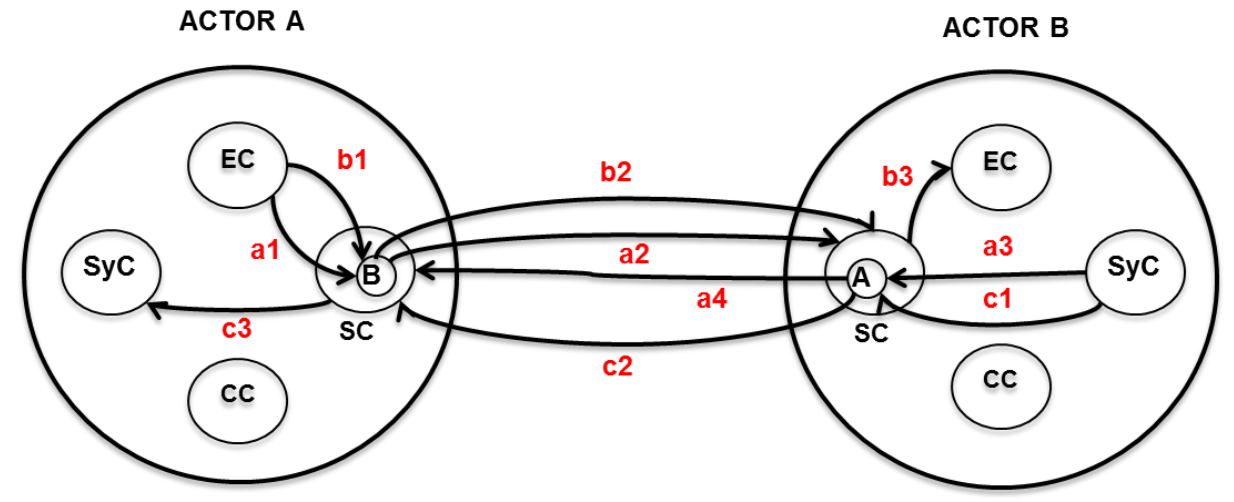

Figure 4: Conversions among the Forms of Capital between two actors

During an interaction between an upper-class actor (A), who, for the purposes of this example, is assumed to have made a financial donation with the intention of acquiring SyC, and a working-class actor (B), who is assumed to have received the donation, thus acquiring EC, actor A first converts his/her EC into his/her SC (a1), and meanwhile actor B converts his/her SyC $C^{\mathrm{x}}$ into his/her SC (a3). Then the two actors connect to each other (a2 and a4), set the stage for interaction, and exchange resources. ${ }^{x i x i i}$ Thus, SC first functions as a connector that links these two actors. Then, the two actors exchange the forms of capital that they intend to exchange with each other. Through the transformations of EC into SC (by actor A-b1), SC into SC (the interaction between the two actors-b2 as the follow-up link of b1), and SC into EC (by actor B-b3) and SyC into SC (by actor B-c1), SC into SC (the interaction between the two actors-c2 as the follow-up link of c1), and SC into SyC (actor A-c3), SC functions as a transmitter that provides these two actors with the opportunity to exchange the necessary forms of capital. That is to say, as a result of the interaction and exchange between actor $\mathrm{A}$ and actor B, actor B receives EC in the form of SC (b1 and b2) and first transforms this SC into EC and second inserts this EC that s/he receives from actor A into his/her capacity of EC (b3). Meanwhile, actor A receives $\mathrm{SyC}$ in the form of SC (c1 and c2) and first transforms this $\mathrm{SC}$ into SyC and second inserts this SyC that s/he receives from actor B into his/her capacity of SyC (c3). If desired, actor B can also convert this EC into CC within himself/herself at the individual level. Again, I would like to point out that all the transformations from or into SC throughout the interactions are conceptual transformations. They occur intangibly to set the stage for actors to interact with each other and exchange whatever forms of capital they need. And these conceptual transformations from or into SC should be examined with the idea that social capital exists neither in objects nor in people, but between human beings (Svendsen, Kjeldsen, \& Noe, 2010).

In sum, it can be asserted that the transformations of EC into CC and CC into EC only occur at the individual level. These transformations do not occur at the group level. The group level transformations occur only through the usage of individuals' SCs. Individuals can acquire other forms of capital from their social connections at the group level only by using their SCs through converting their forms of capital (EC, CC, or SyC) into their SCs and vice 
versa. Afterwards, they insert any forms of capital that they acquire from their social connections to the same form of capital that they have already had through using their SCs.

It is assumed that due to the conversion processes among the forms of capital, an Ego's forms of capital are directly proportional to all other forms of capital for which the Ego has capacity. The more an Ego's EC, the more likely s/he is to have CC, and vice versa, the more an Ego's CC, the more likely s/he is to have EC. The more an Ego's EC, CC, or SyC, the more s/he is able to use his/her SC. And finally, the more an Ego's EC or CC or both, the more likely s/he is to have SyC. Whether the Ego's EC, CC, or SyC provides the highest level of efficiency to SC depends on the field (Bourdieu, 1984) in which individuals compete for valued resources. In cultural fields, for example, it is assumed that an Ego's CC rather than his/her EC gives more efficiency (e.g., usefulness and strength) to his/her SC, and in administrative fields, it is assumed that an Ego's EC rather than his/her CC gives more efficiency to his/her SC in his/her interactions with his/her alters.

So far, I have introduced and developed the basic principles of my model of conversions among the forms of capital through addressing: (1) how CC and EC convert into each other at the individual level, and thus how individuals accumulate $\mathrm{CC}$ or EC at the individual level, (2) how SC functions as a connector that links individuals to each other and provides a stage for them to interact, (3) how SC functions as a transmitter that facilitates the exchange of resources among individuals, and (4) how EC, CC, and SyC can be accumulated using SC at the group level. However, I have not focused on how SC can be accumulated at both the individual and group levels. At the end of this study, this issue will be addressed using Granovetter's (1973) "Strength of Weak Ties" theory.

At the individual level, how an individual accumulates $\mathrm{SC}$ is straightforward. The more an individual has $\mathrm{EC}, \mathrm{CC}$, or $\mathrm{SyC}$, the more s/he is to have SC. It is expected that wealthy and economically well endowed (EC), sophisticated and culturally flexible (CC), and legitimate and recognized (SyC) individuals will have more social connections (SC) that they can access. Looking at the relationship between CC and SC, for example, Lizardo (2006) found that one's cultural preferences are directly related to his/her social network (also see Erickson, 1996). Also, focusing on the relationship between EC and SC, Lin (1999, 2001) and Granovetter (1995) posit that one's social class origin (either advantaged or not) and his/her job (either prestigious or not) are directly related to his/her social network. And finally, addressing the relationship between SyC and SC, Lin (2001, p.158) argues that SyC in the form of recognition "reinforces the legitimacy of certain actors who claim their resources and positions and, at the same time, offers incentives for further social exchanges and unequal transactions among actors, enhancing their social capital."

At the group level, however, the accumulation of SC is more complex. Since an individual's SC is directly and proportionally related to other's volumes of capital (Bourdieu, 1986), I argue that individuals accumulate more SC at the group level in accordance with Granovetter's (1973) explanations of the creation of connections among individuals in his well-known study, The Strength of Weak Ties.

Granovetter (1973, p. 1361) argues, "the strength of a tie is a (probably linear) combination of the amount of time, the emotional intensity, the intimacy (mutual confiding), and the reciprocal services which characterize the tie." In line with Granovetter's definition of the strength of a tie, I argue that compared to individuals who have not met before to interact with each other, those, who have met before and thus converted their volumes of capital (EC, $\mathrm{CC}$, and $\mathrm{SyC}$ ) into their SCs to interact with each other, are more likely to create strong ties 


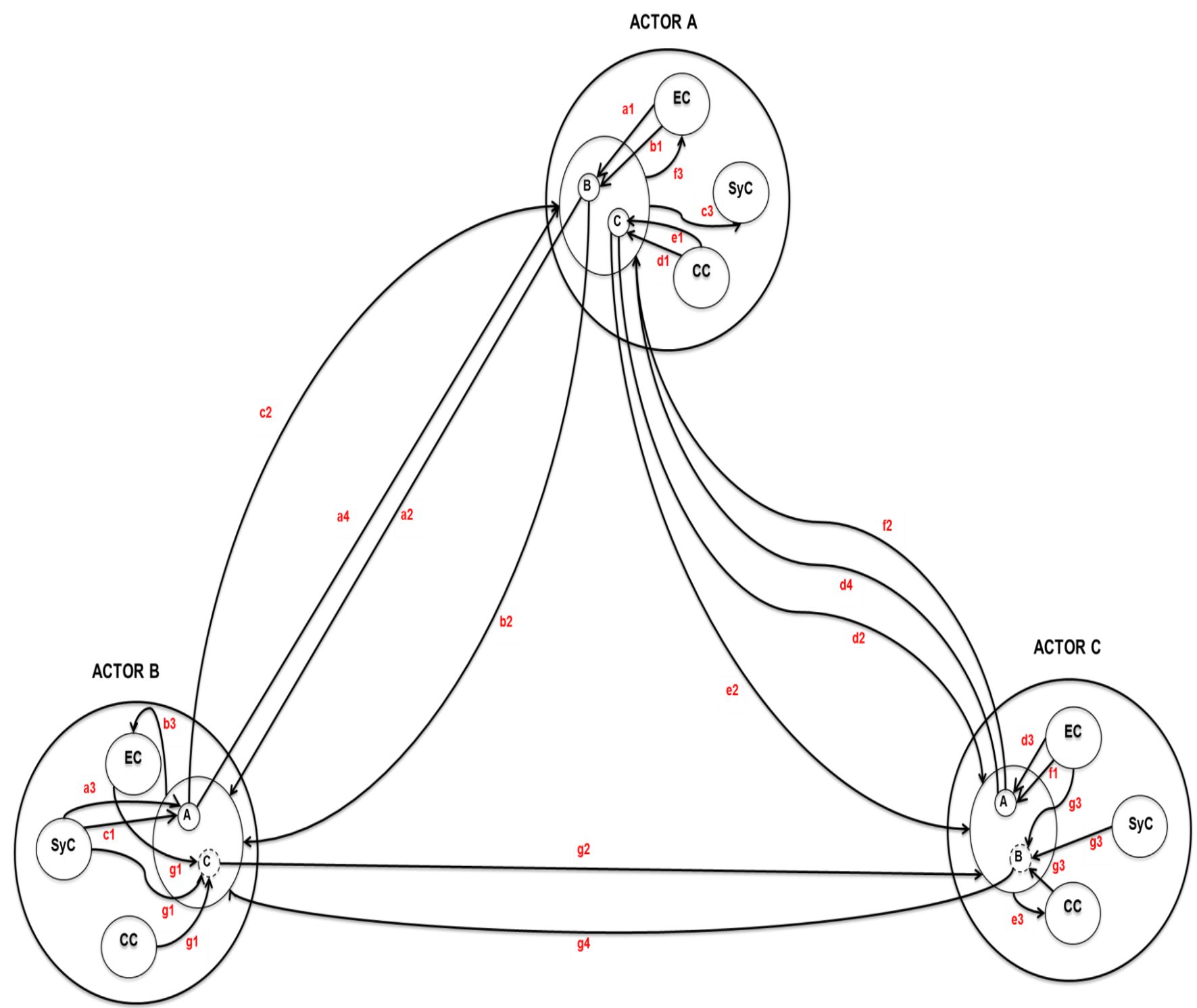

Figure 5: Conversions of the Forms of Capital among three actors

than weak ties between each other. In Figure 5, which provides an illustration of the interactions and exchange of resources among the three actors, actor $\mathrm{A}$ is assumed to have met with actor $\mathrm{B}$ and actor $\mathrm{C}$ before, and actor $\mathrm{B}$ and actor $\mathrm{C}$ are assumed to have not met before. According to Granovetter (1973, p. 1362), "if strong ties connect A to B and A to C, both $\mathrm{B}$ and $\mathrm{C}$, being similar to A (due to the homophily principle), are probably similar to one another, increasing the likelihood of a friendship once they have met." In other words, if an individual has a strong connection with two others by way of strong ties, then it is highly likely that the two others will also be connected to each other, thus producing triadic closure. For that reason, the strong ties between actor $\mathrm{A}$ and actor $\mathrm{B}$ and between actor $\mathrm{A}$ and actor $\mathrm{C}$ create a weak tie between actor B and actor $\mathrm{C}$.

In Figure 5, the small circles in each actor's SCs also show the strength of the ties among them. Since actor B and actor C are unlikely to interact without their ties to actor A, they have dashed circles, which represent their potential social connections that they have not met before, in their SCs. Only by using their strong ties to actor A, they are likely to create a weak tie between each other and interact via that weak tie.

Similar to the interactions and exchange of resources shown in Figure 4, Figure 5 shows how actor A uses his/her strong ties with the other two actors to interact and exchange 
resources with them. In order to do that, actor A first is assumed to exchange his/her EC with actor B's SyC and then exchange his/her CC with actor C's EC. His/her actions are shown in Figure 5 as follows: actor A first converts his/her EC into his/her SC (a1), and meanwhile actor B converts his/her SyC into his/her SC (a3). Then the two actors connect to each other (a2 and a4), set the stage for interaction and the exchange resources. Since these individuals have met before, they only convert the forms of capital that they intend to exchange, thus signifying a strong-tie relationship. Finally, the two actors exchange the forms of capital that they intend to exchange with each other (following the actions of b1, b2, and b3 for actor A's $\mathrm{EC}$, and $\mathrm{c} 1, \mathrm{c} 2$, and $\mathrm{c} 3$ for actor B's SyC).

Actor $\mathrm{A}$ is also assumed to convert his/her $\mathrm{CC}$ into EC by using the strong-tie relationship with actor $\mathrm{C}$. The interaction and exchange of resources between actor $\mathrm{A}$ and actor $\mathrm{C}$ follow the same sequence of actions that actor $\mathrm{A}$ and actor $\mathrm{B}$ use. To set the stage for interaction, actor $\mathrm{A}$ uses the actions entitled $\mathrm{d} 1$ and $\mathrm{d} 2$, and actor $\mathrm{C}$ uses the actions entitled $\mathrm{d} 3$ and $\mathrm{d} 4$. They then exchange their $\mathrm{CC}$ and EC and convert them into EC and CC by using the actions entitled e1, e2, and e3 for actor A's CC, and f1, $\mathrm{f}$, and $\mathrm{f} 3$ for actor C's EC.

The most important factor to consider in Figure 5 (more important than the strong tie connections between actor A and actor B and between actor A and actor C) is the creation of a weak-tie connection between actor $\mathrm{B}$ and actor $\mathrm{C}$. These two actors use their strong ties to actor $\mathrm{A}$ to create a weak tie between themselves, and thus to accumulate more $\mathrm{SC}$ at the group level. Since actor B and actor $\mathrm{C}$ have not met before, to set the stage for interaction and show the other actor their capital capacities before interaction, they first convert their volumes of capital (EC, CC, and SyC) into their SCs (entitled $\mathrm{g} 1$ for actor B and $\mathrm{g} 3$ for actor $\mathrm{C}$ ). Then, as follow-up actions to their intentions (entitled g2 for actor B and $\mathrm{g} 4$ for actor $\mathrm{C}$ ), they connect to each other first to interact and second to exchange resources.

In conclusion, the conversion of the forms of capital is complex and must be examined at both the micro (individual) and macro (group) levels. I argue that even though the conversion processes can best be observed at the micro level within an individual, they can best provide what individuals need at the macro level using SC between individuals. In this sense, Bourdieu's argument of economic capital as the root of all other forms of capital needs to be developed in line with the theoretical conceptualization presented in this study. While, for Bourdieu and for the conversion processes at the individual level, economic capital is at the root of all other forms of capital, this study extends this to argue that social capital is at the root of all other forms of capital at the group level. This conclusion follows since all other forms of capital are reducible and transformable to social capital in order to be converted into other forms at the group level. As Svendsen, Kjeldsen, \& Noe (2010) argue, an individual's volume of capital (EC, CC, and SyC) in the form of the possession of a harmonious mix of tangible and intangible forms of capital, on the one hand, functions as a credit and credibility in the broadest sense of the word. An individual's social capital, on the other hand, should be seen as a "master capital" that allows the individual to access to his/her alters and consequently their volumes of capital and acquire credits and credibility in his/her social network. Therefore, the mastery of the usage of this "master capital" has big potential in determining who is to be a success or a failure in society.

\section{Conclusion}

While Bourdieu (1986) offers significant insight into the nature of the relationship among economic, cultural, and social capital, his unique perspective in the interchangeability among the three forms of capital includes neither the more comprehensive and broader conceptualization of the conversion processes occurring at the macro level, nor the applicability of symbolic capital throughout the conversions. In this study, I have attempted to 
provide a conceptual framework to address the shortcomings of the Bourdieusian model of conversions among the forms of capital through focusing on the functioning of the concept of social capital and its applicability among individuals throughout the conversion processes. While the Bourdieusian model of conversions have often been understood as the relationships among economic, social, and cultural capital within an individual, with the arguments presented in this study, I have enlarged the interdependency assumption among these three forms of capital and provided a comprehensive explanation of the effects of an alters' forms of capital on the Ego's forms of capital.

Beyond Bourdieu's (1986) conceptualization, I have addressed: (1) how an individual's cultural and economic capital convert into each other, and thus how s/he accumulates cultural or economic capital at the individual level, (2) how an individual's social capital functions as a connector that links him/her to his/her alters, and thus provides a stage for interaction, (3) how an individual's social capital functions as a transmitter that allows the exchange of resources between him/her and his/her alters, (4) how an individual's economic, cultural, and symbolic capital can be accumulated by using his/her social capital at the group level, and finally (5) how an individual's social capital can be accumulated at both the individual and group levels.

As a result, the main tenet of the Bourdieusian model of conversions - that is, the liquidity and value of economic capital for the conversions among the forms of capitalrestrains its arguments to the individual level only. The link between the individual level and group level conversions through the conceptualization of social capital as a master capital functioning both as a connector and a transmitter between individuals enlarges Bourdieu's (1986) original conception of the conversion processes. Thus, a more encompassing understanding of the strategies that individuals apply to compete for resources and social positions in the social order can be achieved.

\section{References}

Anheier, H. K., Gerhards, J. \& Romo, F. P. (1995). Forms of capital and social structure in cultural fields: Examining Bourdieu's social topography. American Journal of Sociology. 100, 859-903.

Bourdieu, P. (1977a). Cultural reproduction and social reproduction. In J. Karabel \& A. Halsey (Eds.), Power and ideology in education (pp. 487-511). New York: Oxford University Press.

Bourdieu, P. (1977b). Outline of a theory of practice. Cambridge: Cambridge University Press.

Bourdieu, P. (1984 [1979]). Distinction: A social critique of the judgment of taste. Translated by R. Nice. Cambridge: Harvard University Press.

Bourdieu, P. (1986). The forms of capital. In J. G. Richardson (Eds.), Handbook of theory and research for the sociology of education (pp. 241-258). New York, NY: Greenwood Press.

Bourdieu, P. (1991). Language and symbolic power. Translated by G. Raymond and M. Adamson. Cambridge, Mass.: Harvard University Press.

Bourdieu, P. \& Passeron, J. C. (1977). Reproduction in education, society and culture. London: Sage.

Bourdieu, P. \& Wacquant, L. J. D. (1992). An invitation to reflexive sociology. Chicago, IL: The University of Chicago Press.

Desan, M. H. (2013). Bourdieu, Marx, and capital: A critique of the extension model. Sociological Theory. 31(4), 318-342.

Erickson, B. (1996). Culture, class, and connections. American Journal of Sociology. 102(1), 217-251. 
Granovetter, M. (1973). The strength of weak ties. American Journal of Sociology. 78, 13601380.

Granovetter, M. (1995). Getting a job: A study of contacts and careers, (2nd ed.). Chicago, IL: University of Chicago Press.

Guan, W. A Social Networking Theory on the Conversion of Capital. Unpublished Manuscript.

Lamont, M. \& Lareau, A. (1988). Cultural capital: Allusions, gaps, and glissandos in recent theoretical developments. Sociological Theory. 6, 153-168.

Lin, N. (1999). Social networks and status attainment. Annual Review of Sociology, 25, 467487.

Lin, N. (2001). Social capital: A theory of social structure and action. New York, NY: Cambridge University Press.

Lizardo, O. (2006). How cultural tastes shape personal networks. American Sociological Review. 71, 778-807.

Marx, K. (1995). Capital: A new abridgement. Edited by David McLellan. Oxford: Oxford University Press.

Svendsen, G. L. H., Kjeldsen, C. \& Noe, E. (2010). How do private entrepreneurs transform local social capital into economic capital? Four case studies from rural Denmark. The Journal of Socio-Economics. 39, 631-644.

Swartz, D. (1997). Culture and power: The sociology of Pierre Bourdieu. Chicago: The University of Chicago Press.

\section{Endnotes}

\footnotetext{
${ }^{\mathrm{i}}$ In this study, both the conversion of and the transformation of one form of capital into another form represent the same process. I use the terms, conversion and transformation, throughout this study without attributing different meanings.

${ }^{\text {ii }}$ A discussion around the concept of field is beyond the purpose of this study, but, briefly, fields are structures of the social setting that are organized around specific types of capital. There are many fields as there are forms of capital. For instance, while cultural capital is the key property in the intellectual field, economic capital is the key property in the administrative field. Scientists compete for scientific capital in the field of science, whereas religious authorities compete for religious capital in the field of religion (Bourdieu, 1984, p. 113-114).

iii Bourdieu (1986) distinguishes three types of cultural capital: (1) embodied cultural capital in the form of legitimate cultural attitudes, preferences, and behaviors that are internalized during the socialization process; (2) objectified cultural capital in the form of transmittable goods-books, computers, paintings-that require embodied cultural capital to be appropriated; and (3) institutionalized cultural capital in the form of degrees and diplomas which certify the value of embodied cultural capital (Lamont \& Lareau, 1988, p. 156).

iv In this study, I am not concerned with the other field-specific forms of capital such as religious capital or scientific capital.

${ }^{\mathrm{v}}$ This procedure will be explained in more detail later with examples.

${ }^{v i}$ Differently from the interactions with more pragmatic nature, the more intimate and emotional interactions among individuals (such as love), which do not seek an objective to access to others' volumes of capital, is beyond the scope of this study.

vii The Ego's decision to acquire SyC or accumulate CC or EC by using his/her SC differs depending on (1) the hierarchical position of the Ego, (2) the hierarchical position of the Ego's alter, (3) the type of interaction (homophilous or heterophilous), and (4) the type of action (expressive or instrumental) (Lin, 2001) that the Ego uses to access to his/her alter.

viii The transformation of $\mathrm{EC}, \mathrm{CC}$, or $\mathrm{SyC}$ to $\mathrm{SC}$ is required to ensure the environment for the interactions that might occur between individuals. Each individual, who intends to interact with others, comes to this environment with his/her capital capacities (EC, CC, and SyC). An individual's differentiating levels of the forms of capital and his/her differentiating intentions of transforming which form of capital into which form, determines his/her interactions with others (with whom s/he is going to interact with what purpose).

${ }^{\text {ix }}$ Normally, after two actors connect to each other to exchange resources, this exchange and consequently the transformations of certain forms of capital into other forms for the two actors do not occur simultaneously. According to Bourdieu (1986), for example, the transformation of one's EC into SC or one's EC into CC is a
} 
risky investment since the return of these transformations as EC might not happen, and if happens it might take time. Therefore a simultaneous effort and return should not be expected during the conversion processes. However, for simplicity, in both my explanations and examples, I assume that after the actors connect to each other and consequently transform their volumes of capital into their SCs, all the transactions among them occur simultaneously.

${ }^{x}$ Due to its abstract structure compared to EC and CC, it is important to understand what SyC really is and how it can be converted into SC during the conversion process. SyC does not represent something that individuals have but something that they will lose in certain situations through their interactions with others. While EC and $\mathrm{CC}$ refer to mostly tangible resources that individuals have, SyC refers to intangible resources that individuals will lose. That is the reason why SyC cannot be converted into other forms of capital at the individual level. SyC is not a resource that can be converted into $\mathrm{EC}$ or $\mathrm{CC}$ within an individual. It can only be acquired or lost through the interactions with social connections and through the usage of SC. For instance, when an actor A donates money in the form of $\mathrm{EC}$ to an actor B, SyC might be the response of actor B to actor A in the form of a diminution in actor B's capacities seen as actor B's feeling of indebtedness or his/her feeling of gratitude to actor $\mathrm{A}$ as a response to actor A's donation. While actor B does not lose any kind of tangible resources by sending actor A his/her SyC, this antisymmetric relationship between actor A and actor B strengthens their positions in the structural hierarchy as a dominant actor A and a submissive actor B. If actor A's donation to actor B is heard by others, actor A not only receives SyC from actor B, but also from others who appreciate what actor A does. Thus, the donation that actor A gives to actor B generates social debts for actor B in the form of SyC that s/he sends to actor A and social recognition for actor A in the form of SyC that s/he receives from both actor B and the other individuals.

xi The links entitled a2 and a4 subsequently are not separate from the links entitled a1 and a3, subsequently. The little circles inside each other's SCs represent the other actor they interact with. Therefore, a2 and a4 are followup links of a1 and a3 that were drawn to facilitate the understanding of the interaction between actors.

xii During the interaction, actor A first makes a move towards actor B to interact with him/her. Therefore his/her intention to exchange resources shows itself with the transformation of his/her EC into his/her SC (a1) and his/her part of the interaction (a2). Then, as a response to actor A's intention and part of interaction, actor B responds with the transformation of his/her SyC into SC (a3) to show actor A that s/he intends to interact and his/her part of the interaction (a4) to create the link between him/her and actor A. Who makes the first move depends on what individuals need to exchange with each other, and what sequence this exchange of the forms of capital entails. In this example, actor A has to make the first move since actor B can send his/her SyC only as a return to actor A's effort. SyC follows EC. During an exchange between an actor's EC and another actor's CC, it cannot be definitely said which actor will make the first move since there is no certain rules about the sequence between CC and EC. 